\title{
A VAJDASÁGI, SZABADKAI KÖZÉPISKOLÁBAN DOLGOZÓ TANÁROK MEGLÁTÁSAI AZ ELEKTRONIKAI ÉS MECHANIKAI ISKOLAI VÉDELEM TERÜLETÉN
}

\section{EXPERIENCES OF SECONDARY SCHOOL TEACHERS FROM SUBOTICA, VOJVODINA REGARDING ELECTRONIC AND MECHANICAL PROTECTION AT SCHOOL}

\author{
Bálint Krisztián
}

Óbudai Egyetem, Biztonságtudományi Doktori Iskola, Cím: Magyarország, Budapest, Népszínház utca 8., balint.krisztian@phd.uni-obuda.hu

\begin{abstract}
Adequate security measures at schools are essential, not only in Vojvodina, but in all secondary schools. This work outlines the opinion of secondary school teachers about the mechanical and electronic protection of secondary school institutions. The present research aims to shed light on the significance of school security, and problems caused by its lack, as well as offer suggestions towards increased security and protection.
\end{abstract}

Keywords: mechanical protection, electronic protection, school security, access control system, security camera system.

\section{Összefoglalás}

A középiskolák megfelelő szintű védelme nem csak a vajdasági régióban szükségszerü, hanem minden egyes középiskolában. Jelen kutatás azt hivatott feltárni, hogy a határon túli vajdasági középiskolákban dolgozó tanárok hogyan vélekednek a mechanikai és az elektronikai iskolavédelemről. A kutatás célja, hogy rávilágítson az iskolai biztonság fontosságára, feltárja azok hiányosságait, valamint, hogy javaslatot tegyen a biztonság fokozása érdekében.

Kulcsszavak: mechanikai védelem, elektronikai védelem, iskolai biztonság, beléptetörendszer, biztonsági kamerarendszer.

\section{Bevezető}

A biztonság köznapi értelemben valakinek vagy valaminek a veszélytöl, kártól, jogtalan beavatkozástól, bántódástól védett állapota, helyzete. [1] Ahhoz, hogy az oktatási intézmény zavartalanul tudjon müködni, megfelelő biztonságra van szükség. A középiskolai oktatás nélkülözhetetlen napjainkban, ugyan úgy, mint az elektronikai és a mechanikai iskolavédelem is. A tanulók biztonsága elsődleges szempont kell, hogy legyen.

\section{Mechanikai védelem}

Az oktatási intézmények esetében nem elegendő az elektronikai védelem, hanem ajánlatos azt kibővíteni mechanikai védelmi megoldásokkal is. A mai modern iskolák 
számos technikai eszközökkel rendelkeznek, úgy mint:

- számítógépek,

- projektorok,

- professzionális nyomtatók,

- tabletek, okos telefonok.

Ezeket az eszközöket azonban védeni kell, hiszen a számítógépek számos fontos adatokat tartalmazhatnak, amelyek az iskola müködésében nélkülözhetetlenek, úgy mint:

- elektronikus naplók,

- a tanulók és ott dolgozók személyes adatai,

- adminisztrációs nyilvántartások.

\subsection{Kültéri mechanikai védelem}

A mechanikai védelem már az objektum előterében megkezdődik. A kültéri vagyonvédelmi megoldások és eszközök késleltetik, illetve akadályozzák az illetéktelen behatolót az őrzött területre, valamint objektumba való bejutásban. [2] Az iskolákat gyakran veszik körül kerítések. Ezek a kerítések az oktatási intézmények esetében hatalmas jelentőséggel bírnak. Az iskolaudvaron játszó tanulók védelme kiemelkedő fontosságú.

A média gyakran számol be emberrablásokról, drogárusításról és drogfogyasztásról. Mivel az iskolák nagy része a sürün lakott területek közelében találhatóak, ezért ezeknek a veszélyeknek a tanulók is ki vannak téve. A kerítések, a jól zárható kültéri ajtók jelentősen növelni tudják a tanulók biztonságérzetét és a biztonságát.

\subsection{Mechanikai tárgyvédelem}

A kutatásban részt vett iskolák közül mindegyikében megtalálható a tárgyvédelem tipikus eszköze a széf.

A széfeket egyébként zártípus szerint lehet csoportosítani: létezik kulcsos széf, mechanikus számzáras széf, elektronikus számzáras széf, valamint ezek kombinációi. Zár szempontjából biztonságilag nincs jelentős különbség a komolyabb széfek között, azt kell eldönteni, mi a kényelmesebb megoldás a használónak- a kulcsot magánál tartani, vagy a kódot nem elfelejteni. A kevésbé komoly kategóriás széfek elektromos zárjait, kulcsos vésznyitási lehetőséggel látják el, ennek akkor van jelentősége, ha elfelejtik a kódot, mert ilyenkor a vésznyitó kulcs segítségével, ki lehet nyitni a széfet. A mai modern széfeket müszaki szempontból magasan fejlett technológia jellemez. [3]

\section{3. Építményvédelem}

$\mathrm{Az}$ épületek leggyakoribb behatolási pontjai az ajtók és az ablakok, melyek részben, vagy egészben üvegezettek. Ezen üvegfelületek védelmére sikeresen alkalmazhatóak a biztonsági fóliák. Melyek olyan többrétegü, laminált, müanyag alapú védőelemek, amelyeket az üvegfelületre utólag felerősítve (kasírozva, ragasztva, applikálva stb.) megakadályozzák annak támadás esetén történő azonnali összeesését. Az üvegfelületet egyben tartva, késleltetik a behatoláshoz szükséges nyílás kivágását, és a támadó számára a szilánkképződéssel nagymértékü balesetveszélyt okoznak. A biztonsági fóliák csökkentik az ultraviola sugárzást, színező réteggel is bevonható. [2]

A biztonsági fóliák alkalmazása az általános iskolákban célszerü megoldás, hiszen az ablakráccsal történő megerősítése nem biztos, hogy a lehető legjobb megoldás. Elönyös, ha az oktatási intézmények kellemes benyomást keltenek, olyat, ahol a tanuló jól érzi magát, hiszen a nap nagy részét az oktatási intézmény falain belül tölti. [7]

\section{Elektronikai védelem}

\subsection{Iskolai tűz- és füstjelző berende- zések}

A tüzvédelem területén az evakuálás során jelentkeznek leginkább az emberi tényező hatásai. A veszélyre felkészült tüzoltókkal ellentétben a tanácstalan 
áldozatok nem tudják, hogy milyen irányban és módon kell menekülni az épületből. Tüz esetén az emberek általában nem tudják, hogy mi a helyes magatartás. [4]

Az iskolákban azonban a tanulókkal be lehet gyakoroltatni azokat a kiürítési gyakorlatokat, amelyek tüz esetén akár életeket menthetnek. Ehhez nincs szükség külön anyagi támogatásra, mindössze szervezetés kérdése az egész. A tüzriadó alkalmával a tanulók ez által tudni fogják, hogy mi a helyes magatartás és szükség esetén rendezetten el tudják hagyni az oktatási intézményt.

\subsection{Biztonsági kamerarendszerek}

A biztonsági kamerarendszerek fontos szerepet töltenek be a középiskolákban, hiszen mindenki tudja, az oktatási intézményekben mikor zajlik a tanítás, illetve mikor van az iskolaszünet, amikor is szinte üres az egész épület.

Megkülönböztethetünk kültéri és beltéri kamerarendszert. A kültéri megfigyelő rendszer által az iskola környékét, valamint az udvart lehet szemmel tartani. Az iskolai kamerarendszerek kiépítésénél számos szempontot kell figyelembe venni. Biztonságtechnikai CCTV rendszerek esetén a WLAN hálózatok használta igen nagy rugalmasságot biztosít mind a tervező és kivitelezö, mind az üzemeltető részére. Meglévő hálózat bővítése egy jól megtervezett helyen telepített Access Pointtal a meglévő IP alapú CCTV rendszerünk bővítése megoldható. Ezen a ponton a hálózatfejlesztéshez szükséges sávszélesség számítás igen nagy jelentőségűvé válik. Nem pontos, vagy helytelen kalkuláció esetén előfordulhat, hogy a telepítésre szánt kamera (annak paramétereitől, és beállításától függően) által biztosított video stream nem lesz képes folyamatosan eljutni a DVR-hez, mert a hálózat túlterheltsége miatt egyre több, és több lesz az ún. csomagütközés, amely jelentősen lelassítja a hálózat adatforgalmát. [5]
A biztonságot szem előtt tartva természetesen az informatikai hálózatok esetében használatos titkosítások a kábelnélküli rendszereknél is használhatóak, de azzal számolni kell, hogy a titkosítás megléte növeli a szükséges sávszélességet. [6]

\subsection{Beléptetőrendszerek}

Napjainkban, a középiskolákban is fontos szempont lehet az ellenőrzött beléptetés. A beléptetőrendszerek célja, hogy kiszürjék az illetéktelen személyeket, időben felhívják erre a bent dolgozó személyzet figyelmét, valamint, hogy már a bejáratnál megakadályozzák azok bejutását olyan helyekre, ahova nem jogosultak. Tudvalevő azonban, hogy egy minőséges beléptető rendszer kiépítése komoly beruházásnak számít az iskolák számára, ezért a kutatásban részt vett iskolák közül egyikben sem müködik ilyen rendszer. [8] [9]

\section{Empirikus kutatás}

A vizsgálati mintában 2 határon túli vajdasági középiskola (Bosa Milićević Közgazdasági Középiskola, Vegyészetitechnológia Középiskola) 31 tanára vett részt.

\subsection{Hipotézis}

Feltételezhető, hogy a kutatásban részt vevő középiskolai tanárok egyaránt fontosnak tartják a mechanikai és az elektronikai védelmet.

A kutatásban részt vevő tanárok, iskoláktól függetlenül ( $\mathrm{x}^{2}$ próba: $\mathrm{p}=0,062$ ) arra a kérdésre, hogy melyik védelmet tartják fontosabbnak a mechanikai illetve az elektronikai védelmet a következő válaszokat adták, amelyet az 1. táblázat szemléltet.

A kutatás feltárta, hogy a középiskolai tanárok a mechanikai védelmet fontosabbnak tartják az elektronikai védelemnél. Fontos azonban megjegyezni, 
hogy a két válasz között nagyon kis különbség mutatkozik.

1. táblázat. Ön a mechanikai, illetve az elektronikai védelmet tartja fontosabbnak az általános iskolákban? $(n=31)$

\begin{tabular}{|l|c|c|}
\hline \multicolumn{1}{|c|}{ Iskolák } & $\begin{array}{c}\text { Mechanikai } \\
\text { védelem }\end{array}$ & $\begin{array}{c}\text { Elektronikai } \\
\text { védelem }\end{array}$ \\
\hline $\begin{array}{l}\text { Bosa Milićević } \\
\text { Közgazdasági } \\
\text { Középiskola }\end{array}$ & $54 \%$ & $46 \%$ \\
\hline $\begin{array}{l}\text { Vegyészeti- } \\
\text { technológia } \\
\text { Középiskola }\end{array}$ & $51 \%$ & $49 \%$ \\
\hline
\end{tabular}

A tanárok a válaszaikat azzal indokolták, hogy egy zárat, vagy ajtót megerösíteni a meglátásaik szerint kevesebb költséggel jár, mint egy modern iskolai elektronikai biztonsági rendszert kiépíteni, holott erre is nagy igény mutatkozna. Továbbá a válaszaikban kifejtették, hogy a véleményük szerint az iskolák szerény anyagi költségvetéssel gazdálkodnak. A kutatásban részt vett iskolák közül egyikében sincs telepítve biztonsági kamerarendszer, azonban a tüzvédelmi elöírásoknak megfelelően füst és tüzjelzó berendezések igen.

\section{Következtetések}

A kutatás feltárta, hogy a középiskolában dolgozó tanárok a mechanikai és az elektronikai védelmet is fontosnak tartják. Sajnálatos módon azonban modern biztonsági rendszereket nem tudnak kiépíteni az iskolák a szerény anyagi költségvetésükből kifolyólag, holott ők lehetőség függvényében növelnék a jelenlegi biztonsági szintjüket.

\section{Szakirodalmi hivatkozások}

[1] Kiss Sándor: A biztonságtechnika kialakulásának történetéröl. Hadmérnök 10.4 (2015): 24-29.

[2] Berek Lajos: Biztonságtechnika. (2014).

[3] Rácz László István: Objektumvédelem, különös tekintettel a szállodavédelemre. Hadmérnök 5.1 (2011).

[4] Schüller Attila: Az emberi tényező és a technikai megvalósitások vizsgálata tüzriadók során. Hadmérnök 2012. 2. Szám, 37-46.

[5] Horváth Tamás: Kábelek, hálózatok, CCTV rendszerek. Hadmérnök 6.3 (2011).

[6] Horváth Tamás: IP alapú CCTV rendszer? Hadmérnök 6.2 (2011).

[7] Berek Tamás, Imre Elek: Zárszerkezet, mint a mechanikai védelem sebezhetö pontja Müszaki Katonai Közlöny XXV. 3., 47-58 (2015)

[8] Berek Tamás: ABV (CBRN) analitikai laboratórium beléptetőrendszere a biztonságos üzemeltetés szolgálatában. 21-36. Hadmérnök 6. 2. (2011).

[9] Berek Lajos, Dávidovits Zsuzsanna: Vízbázisvédelem, ivóvízbiztonság. Bolyai szemle 21. 2., 27-38. (2012) 